\title{
Electrochemical and Infrared Spectroelectrochemical Characterization of Self-Assembled Monolayers of a Carbonyl-Coordinated Trinuclear Ruthenium Complex on a Gold Electrode
}

\author{
Masaaki ABE, Shen YE, Toshihiro KONDO, Kohei UOSAKI, ${ }^{*}$ and Yoichi SASAKI* \\ Division of Chemistry, Graduate School of Science, Hokkaido University (Kita-ku, Sapporo 060-0810, Japan) \\ Received June 28, 1999 ; Accepted August 3, 1999 \begin{abstract}
nal $\mathrm{CO}$ ligand were constructed on $\mathrm{Au}(111)$ electrode surface and were characterized by cyclic voltammetry and in situ Fourier transform infrared reflection absorption spectroscopy (FT-IRRAS). A distinctive infrared $\nu$ (CO) absorption band was observed at $1950 \mathrm{~cm}^{-1}$ for the original $\left\{\mathrm{Ru}^{\mathrm{II}}-\mathrm{CO}\right\} \mathrm{Ru}^{\mathrm{III}} \mathrm{Ru}^{\mathrm{III}}$ complex in an aqueous $0.1 \mathrm{M}$ $\mathrm{NaClO}_{4}$ solution and it shifted to $2060 \mathrm{~cm}^{-1}$ upon one-electron oxidation of the $\mathrm{Ru}^{\mathrm{II}}$ center.
\end{abstract} \\ Novel self-assembled monolayers of a mixed-valent $\left(\mu_{3}\right.$-oxo)triruthenium(II,III,III) complex containing a termi-
}

Key Words : Infrared Spectroelectrochemistry, Self-Assembled Monolayers, Trinuclear Ruthenium Complex, Carbonyl Ligand

\section{Introduction}

Recent advances in the interfacial chemistry of ordered molecular assemblies, particularly selfassembled monolayers (SAMs) on electrodes, include construction of those incorporating chemically and biologically interesting materials with specific functionalities. Variable inorganic and organometallic compounds have been chosen to modify electrode surfaces. In this regard, ruthenium complexes are quite attractive owing to their known rich redox chemistry along with the photophysical and catalytic properties. ${ }^{1-4)}$ We have reported very recently selfassembled monolayers on gold electrodes based upon redox-active $\left(\mu_{3}\right.$-oxo)triruthenium(III) complexes ${ }^{5)}$ as well as ( $\mu$-oxo)diiron(III) complexes. ${ }^{6)}$ The acetatebridged $\left(\mu_{3}-0 \times 0\right)$ triruthenium(III) complexes $\left[\mathrm{Ru}^{\mathrm{III}}{ }_{3}\right.$ $\left.\left(\mu_{3}-\mathrm{O}\right)(\mu-\mathrm{OAc})_{6} \mathrm{~L}_{3}\right] \quad\left(\mathrm{OAc}=\mathrm{CH}_{3} \mathrm{CO}_{2}{ }^{-} ; \mathrm{L}=\mathrm{a}\right.$ monodentate terminal ligand $)^{7}$ are quite attractive molecules as a modifier for gold surfaces due to the following electrochemical and reactivity properties. They exhibit multistep reversible redox processes in non-aqueous media. ${ }^{8-10)}$ Their electronic properties can be modulated by changing terminal ligands and carboxylate bridges. ${ }^{8,9)}$ Specifically, an introduction of a strong $\pi$-accepting ligand $\mathrm{CO}$ into one of three ruthenium centers dramatically alters structural, spectroscopic and electrochemical properties of the cluster. ${ }^{8,10)}$ The $\mathrm{CO}$ liberation was observed in solution upon chemical oxidation or UV-illumination. ${ }^{11)}$ The $\nu(\mathrm{CO})$ absorption band in the infrared vibrational spectra can be used to assign the oxidation states of each $\mathrm{Ru}$ centers in electrochemically-generated species $\left[\mathrm{Ru}_{3}\left(\mu_{3}-\mathrm{O}\right)(\mu-\mathrm{OAc})_{6}(\mathrm{CO})(\mathrm{py})_{2}\right]^{n+}$ with $n=-1$, 0,1 , and 2 (py=pyridine) ${ }^{12)}$ and is also an excellent probe to estimate intramolecular electron-transfer rates for the ligand-bridged triruthenium complexes. ${ }^{13)}$

Here we report self-assembly of a new COcontaining mixed-valent triruthenium(II,III,III) complex with a disulfide ligand, $\left[\mathrm{Ru}_{3}\left(\mu_{3}-\mathrm{O}\right)(\mu-\mathrm{OAc})_{6}(\mathrm{CO})\right.$ $(\mathrm{MeIm})(\mathrm{C} 2 \mathrm{PY})]$ (1, MeIm=1-methylimidazole, $\left.\mathrm{C} 2 \mathrm{PY}=\left\{\mathrm{S}\left(\mathrm{CH}_{2}\right)_{2} \mathrm{C}(\mathrm{O}) \mathrm{NHCH}_{2} \mathrm{C}_{5} \mathrm{H}_{4} \mathrm{~N}\right\}_{2}{ }^{14)}\right)$, onto a gold electrode. Along with a terminal $\mathrm{CO}$ and $\mathrm{MeIm}$ ligands, 1 contains one disulfide ligand $\mathrm{C} 2 \mathrm{PY}$ as a tether to the gold electrode to prepare denselypacked, structurally-ordered monolayers on surface. In this communication, electrochemical behavior and in situ Fourier transform infrared reflection absorption spectroscopic characterization of the gold/ SAMs, $1 / \mathrm{Au}$, are described.

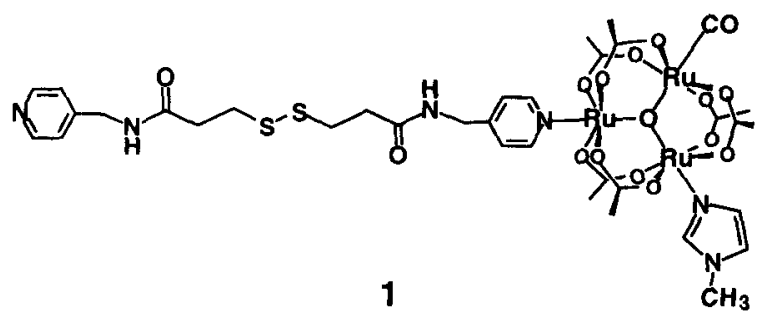

2 Experimental

Complex 1 was synthesized by the reaction of $\left[\mathrm{Ru}_{3}\right.$ $\left.\left(\mu_{3}-\mathrm{O}\right)(\mu-\mathrm{OAc})_{6}(\mathrm{CO})(\mathrm{MeIm})\left(\mathrm{H}_{2} \mathrm{O}\right)\right]$ with $\mathrm{C}_{2} \mathrm{PY}^{14)}$ and was fully characterized by ${ }^{1} \mathrm{H}$ NMR, UV-vis, and IR spectroscopies along with FAB mass spectrometry. ${ }^{15)}$ Analytical data of 1 . Calculated for $1 \cdot 2 \mathrm{H}_{2} \mathrm{O}: \mathrm{C}, 33.47$; $\mathrm{H}, 4.14 ; \mathrm{N}, 8.22 ; \mathrm{S}, 4.70 ; \mathrm{Cl}, 2.60$. Observed: C, 33.50; H, $3.97 ; \mathrm{N}, 8.59 ; \mathrm{S}, 4.66 ; \mathrm{Cl}, 2.77$. Cyclic voltammetry of $\mathbf{1}$ was performed using $0.1 \mathrm{M} \mathrm{TBAPF} / \mathrm{CH}_{3} \mathrm{CN}$ solution $\left(\mathrm{TBA}=\left(n-\mathrm{C}_{4} \mathrm{H}_{9}\right)_{4} \mathrm{~N}^{+}, \mathrm{M}=\mathrm{mol} \mathrm{dm}^{-3}\right)$ with a glassy 
carbon working electrode $(\phi=6 \mathrm{~mm})$, a $\mathrm{Pt}$ wire counter electrode, and an $\mathrm{Ag} / \mathrm{AgCl}$ reference electrode. The half-wave potential $E_{1 / 2}\left\{=\left(E_{\mathrm{pc}}+E_{\mathrm{pa}}\right) / 2\right\}$ and the peak-to-peak separation $\Delta E_{\mathrm{p}}\left(=\mathrm{E}_{\mathrm{pa}}-\mathrm{E}_{\mathrm{pc}}\right)$ of 1 at a scan rate of $100 \mathrm{mV} \mathrm{s}^{-1}$ are as follows: $+0.62 \mathrm{~V}$ $\left(\Delta E_{p}=70 \mathrm{mV}\right):\left\{\mathrm{Ru}^{\mathrm{II}}-\mathrm{CO}\right\} \mathrm{Ru}^{\mathrm{III}} \mathrm{Ru}^{\mathrm{III}} /\left\{\mathrm{Ru}^{\mathrm{III}}-\mathrm{CO}\right\} \mathrm{Ru}^{\mathrm{II}}$ $\left.\mathrm{Ru}^{1 I I}\right) ;+1.25$ V $(60 \mathrm{mV}):\left\{\mathrm{Ru}^{\mathrm{III}}-\mathrm{CO}\right\} \mathrm{Ru}^{\mathrm{II}} \mathrm{Ru}^{1 \mathrm{III}} /$ $\left\{\mathrm{Ru}^{\mathrm{III}}-\mathrm{CO}\right\} \mathrm{Ru}^{+3.5} \mathrm{Ru}^{+3.5} ;-0.96$ V $(70 \mathrm{mV}):\left\{\mathrm{Ru}^{\mathrm{II}}-\right.$ CO $\} \mathrm{Ru}^{\mathrm{III}} \mathrm{Ru}^{\mathrm{III}} /\left\{\mathrm{Ru}^{1 \mathrm{II}}-\mathrm{CO}\right\} \mathrm{Ru}^{+2.5} \mathrm{Ru}^{+2.5} ; E_{\mathrm{pc}}=-1.96 \mathrm{~V}$ (irreversible). The assignment is based on the previous FT-IRRAS study of $\left[\mathrm{Ru}_{3}\left(\mu_{3}-\mathrm{O}\right)(\mu-\mathrm{OAc})_{6}(\mathrm{CO})\right.$ $\left.(\mathrm{py})_{2}\right]^{n+}$ in $\mathrm{CH}_{3} \mathrm{CN}^{12)}$ Under the present experimental conditions, one-electron reversible wave of ferrocene $(1 \mathrm{mM})$ was detected at $E_{1 / 2}=+435 \mathrm{mV}$ with the $\Delta E_{\mathrm{p}}$ of $60 \mathrm{mV}$.

The Au(111) electrode $(\phi=10 \mathrm{~mm})$ was prepared as described previously. ${ }^{16)}$ Self-assembled monolayers $1 /$ $\mathrm{Au}$ with the surface coverage $8.4 \times 10^{13} \mathrm{Ru}_{3}$ molecules . $\mathrm{cm}^{-2}$ (based on the integration of a reversible $\mathrm{Ru}_{3}$ based $1 e^{-}$redox wave, vide supra) was constructed by immersing a freshly prepared $\mathrm{Au}(111)$ electrode into a $\mathrm{MeOH} / \mathrm{EtOH}(1 / 2, \mathrm{v} / \mathrm{v})$ solution containing $1(1 \mathrm{mM})$ at $25{ }^{\circ} \mathrm{C}$. Cyclic voltammetry of $1 / \mathrm{Au}$ was performed with a $\mathrm{Pt}$ wire as the counter electrode and an $\mathrm{Ag} /$ $\mathrm{AgCl}$ as the reference electrode using $0.1 \mathrm{M} \mathrm{NaClO}_{4}$ aqueous solution at $25^{\circ} \mathrm{C}$.

The in situ FT-IRRAS measurements ${ }^{17,18)}$ were carried out on a Bio-Rad FTS30 spectrometer equipped with a liquid $\mathrm{N}_{2}$-cooled $\mathrm{HgCdTe}$ detector. A thin-layer IR spectroelectrochemical cell with a $\mathrm{CaF}_{2}$ window was used. The incident angle of the infrared beam was approximately $65^{\circ}$ and p-polarized incident light was used. The spectra were recorded at the sample and reference potentials with a resolution of 4 $\mathrm{cm}^{-1}$. The reference spectrum was recorded at $0 \mathrm{mV}$. The results are presented in the form of the normalized change of reflectance, $\Delta R / R$, which is equal to $\left(R_{\mathrm{s}}-R_{\mathrm{r}}\right) / R_{\mathrm{s}}$, where $R_{\mathrm{s}}$ and $R_{\mathrm{r}}$ represent reflectance at the sample and the reference potentials, respectively. The upward and downward peaks in the spectra indicate a decrease and an increase of the absorption at the sample potential, respectively, with respect to that of the reference potential.

\section{Results and Discussion \\ 3. 1 Cyclic voltammetry of $1 / \mathrm{Au}$ in water}

The cyclic voltammograms (CVs) of $\mathbf{1} / \mathrm{Au}$ in $0.1 \mathrm{M}$ $\mathrm{NaClO}_{4}$ aqueous solution ( $\mathrm{pH}=4.5$, phosphate buffer) at various scan rates are presented in Fig. 1. A well-defined reversible one-electron redox process was observed at $E_{1 / 2}=+620 \mathrm{mV}$ vs. $\mathrm{Ag} / \mathrm{AgCl}$, which was ascribed to the one-electron redox reaction of $\mathbf{1}$, i.e., $\left\{\mathrm{Ru}^{\mathrm{II}}-\mathrm{CO}\right\} \mathrm{Ru}^{\mathrm{III}} \mathrm{Ru}^{\mathrm{III}} /\left\{\mathrm{Ru}^{\mathrm{III}}-\mathrm{CO}\right\} \mathrm{Ru}^{\text {III }} \mathrm{Ru}^{\text {III }}$. The $E_{1 / 2}$ value is consistent with that observed for 1 in 0.1 $\mathrm{M} \mathrm{TBAPF} 6 / \mathrm{CH}_{3} \mathrm{CN}$ (see Experimental Section). As expected for surface attached redox-active centers, the peak current of the redox wave of $1 / \mathrm{Au}$ linearly increased with increasing the scan rate $(20-500 \mathrm{mV}$ $\mathrm{s}^{-1}$.

\section{2 In situ FT-IRRAS measurements for 1/Au}

In situ F'T-IRRAS measurements were employed to characterize 1/Au. Figure 2 shows the spectral changes of $1 / \mathrm{Au}$ in the region of $2300-1300 \mathrm{~cm}^{-1}$ depending on applied potentials $(400-800 \mathrm{mV}$ vs. $\mathrm{Ag} /$ $\mathrm{AgCl}$ ) in $0.1 \mathrm{M} \mathrm{NaClO}_{4}$ aqueous solution. The reference potential was $0 \mathrm{mV}$, where the complex exists as $\left\{\mathrm{Ru}^{\mathrm{II}}-\mathrm{CO}\right\} \mathrm{Ru}^{\mathrm{III}} \mathrm{Ru}^{\mathrm{III}}$. As expected from the CVs (Fig. 1 ), infrared spectral change was not seen at $400 \mathrm{mV}$, where no redox process was involved (Fig. 2a). When the sample potential was applied to more positive than $+600 \mathrm{mV}$ (Figs. 2b-d), at which $1 e^{-}$oxidation of the surface $\mathrm{Ru}_{3}$ complexes started, the growth of a upward peak at $1950 \mathrm{~cm}^{-1}$ and a downward, rather broad peak at $2060 \mathrm{~cm}^{-1}$ were observed. The former

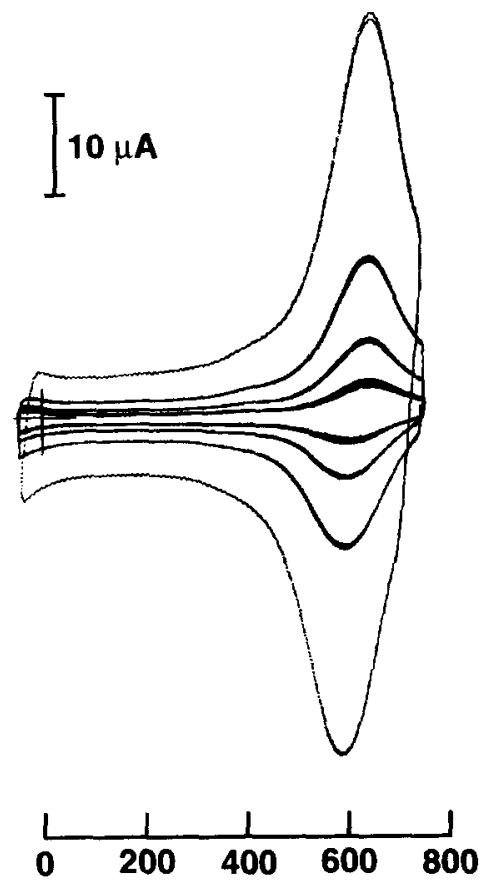

\section{E / mV vs. Ag/AgCl}

Fig. 1 Cyclic voltammograms of $1 / \mathrm{Au}$ in $0.1 \mathrm{M} \mathrm{NaClO}_{4}$ aqueous solution ( $\mathrm{pH}=4.5$, phospate buffer) at scan rates of $20,50,200$, and $500 \mathrm{mV} \mathrm{s}^{-1}$ at room temperature.

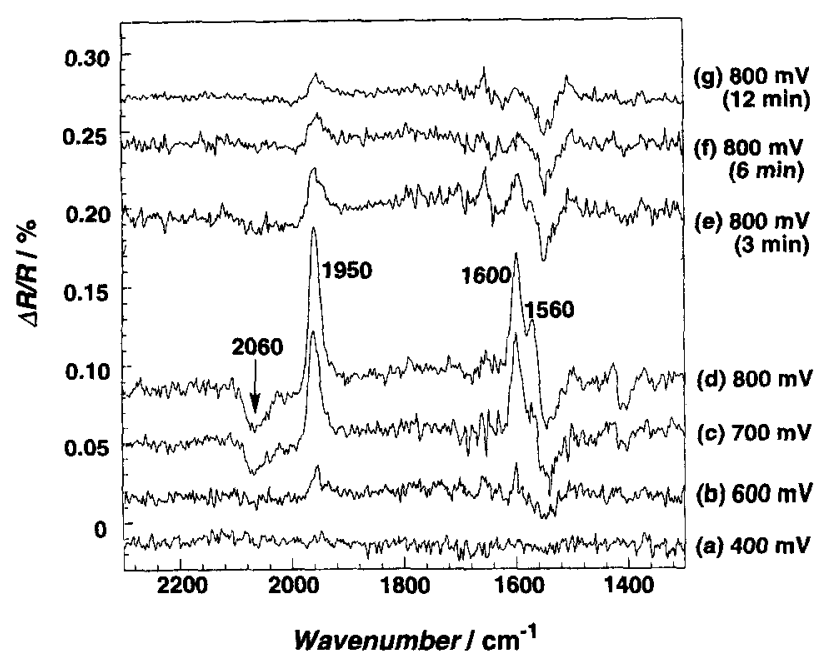

Fig. 2 In situ FT-IRRAS spectra of $1 / \mathrm{Au}$ in $0.1 \mathrm{M}$ $\mathrm{NaClO}_{4}$ aqueous solution in the $2300-1300 \mathrm{~cm}^{-1}$ region. 
corresponds to the $\nu(C O)$ band of the original $\left\{\mathrm{Ru}^{\mathrm{II}}\right.$. $\mathrm{CO} \mathrm{Ru}^{\mathrm{III}} \mathrm{Ru}^{\mathrm{III}}$ complex while the latter is attributed to that of the $1 e^{-}$oxidized $\left\{\mathrm{Ru}^{\mathrm{III}}-\mathrm{CO}\right\} \mathrm{Ru}^{\mathrm{III}} \mathrm{Ru}^{\mathrm{III}} \mathrm{com}-$ plex. ${ }^{12)}$ The significant shift of the $\nu(\mathrm{CO})$ band to the higher frequency upon $1 e^{-}$oxidation of $1 / \mathrm{Au}$ is in good agreement with that observed for $\left[\mathrm{Ru}_{3}\left(\mu_{3}-\mathrm{O}\right)(\mu\right.$ $\left.-\mathrm{OAc})_{6}(\mathrm{CO})(\mathrm{py})_{2}\right]^{\mathrm{n}+}$ in $0.1 \mathrm{M} \mathrm{TBAPF} / \mathrm{CH}_{3} \mathrm{CN}(1940$ $\mathrm{cm}^{-1}$ for $n=0$ and $2055 \mathrm{~cm}^{-1}$ for $\left.n=1\right){ }^{12)}$ Two upward bands at 1600 and $1560 \mathrm{~cm}^{-1}$ are attributed to the asymmetric stretching of the bridging acetates of the $\left\{\mathrm{Ru}^{\mathrm{II}}-\mathrm{CO}\right\} \mathrm{Ru}^{\mathrm{III}} \mathrm{Ru}^{\mathrm{III}}$ complex (Fig. 2d).

The stability of the electrochemically-generated $\left\{\mathrm{Ru}^{\mathrm{III}}-\mathrm{CO}\right\} \mathrm{Ru}^{\mathrm{II}} \mathrm{Ru^{II }}$ complexes on gold was examined. When the potential was maintained at 800 $\mathrm{mV}$ for $3 \mathrm{~min}$ or longer, two $\nu(\mathrm{CO})$ absorption peaks became smaller (Figs. 2e,f). After the electrolysis was achieved for $12 \mathrm{~min}$, the $\nu(\mathrm{CO})$ band due to the $\left\{\mathrm{Ru}^{\mathrm{III}}-\mathrm{CO}\right\} \mathrm{Ru}^{\mathrm{III}} \mathrm{Ru}^{\mathrm{III}}$ was completely suppressed (Fig. $2 \mathrm{~g}$ ). This indicates that $1 e^{-}$oxidized $\mathrm{Ru}_{3}$ species on gold is not stable. We propose that observed spectral change for $1 / \mathrm{Au}$ during electrolysis is principally ascribed to the liberation of the coordinated $\mathrm{CO}$ upon the oxidation of the $\mathrm{Ru}^{\mathrm{II}}$ center to $\mathrm{Ru}^{\mathrm{III}}$. The sixth coordination site of $\mathrm{Ru}^{\mathrm{III}}$ thus formed may subsequently be occupied by a water molecule supplied from the aqueous media used. This interpretation is supported by the observation of a decrease in the current intensity of the CO complex-based redox wave in CVs of $\mathbf{1 /}$ $\mathrm{Au}(+620 \mathrm{mV})$ upon repeated potential scans $(-200$ $\mathrm{mV}$ to $+800 \mathrm{mV}$ ) with a concomitant increase of a new reversible wave at $E_{1 / 2}=-30 \mathrm{mV}$ which closely matches the redox potential observed for a mono(aqua) triruthenium analog $\left[\mathrm{Ru}_{3}\left(\mu_{3}-\mathrm{O}\right)(\mu-\right.$ $\left.\mathrm{OAC})_{6}(\mathrm{MeIm})_{2}\left(\mathrm{H}_{2} \mathrm{O}\right)\right]^{\div}$in $0.1 \mathrm{M} \mathrm{TBAPF} / \mathrm{CH}_{3} \mathrm{CN}\left(E_{1 / 2}\right.$ $(+1 / 0)=-80 \mathrm{mV}$ vs. $\mathrm{Ag} / \mathrm{AgCl}){ }^{19)}$ It should be noted that the less stable character of the gold/SAMs $1 / \mathrm{Au}$ is in contrast with the case of complex 1 dissolved in $\mathrm{CH}_{3} \mathrm{CN}$ where no voltammetric change was observed during repeated scans in the same potential region.

\section{Conclusion}

This paper presents the first example of selfassembled monolayers of carbonyl containing metal cluster complexes which exhibit a reversible redox process in aqueous media. Two oxidation levels of the surface-ordered triruthenium complexes, $\left\{\mathrm{Ru}^{\mathrm{II}}-\mathrm{CO}\right\}$. $\mathrm{Ru}^{\mathrm{II}} \mathrm{Ru}^{\mathrm{III}}$ and the one-electron oxidized $\left\{\mathrm{Ru}^{11 \mathrm{II}}-\mathrm{CO}\right\}$ $\mathrm{Ru}^{\mathrm{III}} \mathrm{Ru}^{\mathrm{III}}$, were characterized by in situ FT-IRRAS measurements. While the FT-IRRAS spectral variations of $1 / \mathrm{Au}$ during the oxidation process were quite similar to those obtained for the triruthenium complex analog in $\mathrm{CH}_{3} \mathrm{CN}$ solution, the stability of the oxidized clusters $\left\{\mathrm{Ru}^{\mathrm{III}}-\mathrm{CO}\right\} \mathrm{Ru}^{\mathrm{III}} \mathrm{R} \mathrm{u}^{\mathrm{III}}$ attached on the gold electrode was significantly lowered.

\section{Acknowledgment}

This work was supported by a Grant-in-Aid for Scientific Research Nos. 10133201 and 09237101 (Priority Area of "Electrochemistry of Ordered Interfaces") and No. 09740483 from the Ministry of Education, Science, Sports, and Culture of Japan.

\section{References}

1) M. S. Ravenscroft and H. O. Finklea, J. Phys. Chem., 98, 3843 (1994).

2) Y. Sato and K. Uosaki, Bull. Chem. Soc. Jpn., 57, 384 (1995).

3) J. P. Collman, M. S. Ennis, D. A. Offord, L. L. Chung, and J. H. Griffin, Inorg. Chem., 35, 1751 (1996).

4) J. Luo and S. S. Isied, Langmuir, 14, 3602 (1998).

5) M. Abe, T. Kondo, K. Uosaki, and Y. Sasaki, J. Electroanal. Chem., 473, 93 (1999).

6) T. Inomata, M. Abe, T. Kondo, K. Umakoshi, K. Uosaki, and Y. Sasaki, Chem. Lett., 1999, 1097.

7) R. D. Cannon and R. P. White, Prog. Inorg. Chem., 36, 195 (1988).

8) J. A. Baumann, D. J. Salmon, S. T. Wilson, T. J. Meyer, and W. E. Hatfield, Inorg. Chem., 17, 3342 (1978).

9) M. Abe, Y. Sasaki, T. Yamaguchi, and T. Ito, Bull. Chem. Soc. Jpn., 65, 1585 (1992).

10) M. Abe, Y. Sasaki, Y. Yamada, K. Tsukahara, S. Yano, T. Yamaguchi, M. Tominaga, I. Taniguchi, and T. Ito, Inorg. Chem., 35, 6724 (1996).

11) H. Kido, H. Nagino, and T. Ito, Chem. Lett., 1996, 745.

12) S. Ye, H. Akutagawa, K. Uosaki, and Y. Sasaki, Inorg. Chem., 34, 4527 (1995).

13) T. Ito, T. Hamaguchi, H. Nagino, T. Yamaguchi, H. Kido, I. S. Zavarine, T. Richmond, J. Washington, and C. P. Kubiak, J. Am. Chem. Soc., 121, 4625 (1999).

14) T. T. Ehler, N. Malmberg, K. Carron, B. P. Sullivan, and L. J. Noe, J. Phys. Chem. B, 101, 3174 (1997).

15) Synthetic procedures and characterization data of 1 and the starting material will be described elsewhere.

16) T. Kondo, S. Horiuchi, I. Yagi, S. Ye, and K. Uosaki, J. Am. Chem. Soc., 121, 391 (1999).

17) S. Ye, A. Yashiro, Y. Sato, and K. Uosaki, J. Chem. Soc., Faraday Trans., 92, 3813 (1996).

18) S. Ye, Y. Sato, and K. Uosaki, Langmuir, 13, 3157 (1997).

19) To be submitted. 